\title{
Політологія
}

DOI: $10.15421 / 172065$

УДК: 327

\section{Theoretical Framework of Democratic Transition: Mechanisms of Democratization}

\section{Mustafa Harb, V. N. Karazin Kharkiv National University}

Democratic transition from authoritarian rule has been an important focus of scholarly interest since 1970s. The democratic transition literature presented many concepts, theoretical arguments, methodological and analytical approaches to tackle with this phenomenon. This huge academic accumulation came in conjunction with what was called the third wave of democratization which started in the mid-seventies beginning from southern Europe, and extended during the decades of the eighties and nineties to include many countries around the globe. Democratic transition can be defined as a political process of establishing or enlarging the possibility of democratic participation and liberalization. This process reflects the redistribution of power between the state and the civil society. It is accompanied by the appearance of different centers of power and the introduction of the political debate. The article concentrates on the mechanisms which lead to the consensus between political actors which perform this democratic transformation. Democratic transition thus always requires a mechanism of negotiations, political talks, facilitating compromises between authoritarian politicians and democratic opposition and engendering a minimum level of trust between these parties. The strategy of political compromise has a major impact on the stability of society during the democratic transition period.

This article addresses the concept of democratic transition alongside with general theories of democratization and the emergence of democratic transition studies. It focuses on some aspects in explaining the democratic transition theory. The negotiations, political talks and their impact on democratic transitions are also explored by the author. The article specifies the ways and methods through which the democratic transition is taking place in the global world.

Keywords: democratic transitions, concept of democratic transition, theories related to democratic transition, waves of democratization, Arabic countries, mechanisms of democratic transition, political talks, political actors, political compromise

\section{Теоретичні основи демократичного переходу: механізми демократизації}

\section{Мустафа Харб, Харківський національний університет ім. В.Н. Каразіна}

Демократичний перехід від авторитарного правління був важливим напрямком наукових інтересів 3 1970-х років. Література про демократичний перехід представила багато понять, теоретичні аргументи, методологічні та аналітичні підходи для подолання цього явища. Це величезне академічне нагромадження відбулося в поєднанні з тим, що називалося третьою хвилею демократизації, яка почалася в середині сімдесятих років, починаючи з півдня Європи, і поширилася протягом десятиліть вісімдесятих та дев"яностих років, увібравши в себе багато країн світу. Демократичний перехід можна визначити як політичний процес встановлення або розширення можливості демократичної участі та лібералізації. Цей процес відображає перерозподіл влади між державою та громадянським суспільством. Він супроводжується появою різних центрів влади та запровадженням політичної дискусії. Стаття зосереджена на механізмах, що призводять до консенсусу між політичними суб”'єктами, які здійснюють цю демократичну трансформацію. Демократичний перехід, таким чином, завжди вимагає механізму переговорів, політичних обговорень, полегшення компромісів між авторитарними політиками та демократичною опозицією та, створення мінімального рівня довіри між цими сторонами. Стратегія політичного компромісу має великий вплив на стабільність суспільства в період демократичного переходу.

У цій статті розглядається концепція демократичного переходу разом із загальними теоріями демократизації та появою досліджень про демократичний перехід. Основна увага приділяється деяким аспектам 
пояснення теорії демократичного переходу. Автор також досліджує переговори, політичні обговорення та їх вплив на демократичні переходи. У статті визначено шляхи та методи, за допомогою яких відбувається демократичний перехід у цілому світі.

Ключові слова: демократичні переходи, кониееція демократичного переходу, теорії пов"язані з демократичним переходом, хвилі демократизації, арабські краӥни, механізми демократичного переходу, політичні переговори, політичні актори, політичний компроміс

\section{Теоретические основы демократического перехода: механизмы демократизации}

\section{Мустафа Харб, Харьковский национальный университет им. В. Н. Каразина}

Демократичний перехід від авторитарного правління був важливим напрямком наукових інтересів 3 1970-х років. Література про демократичний перехід представила багато понять, теоретичні аргументи, методологічні та аналітичні підходи для подолання цього явища. Це величезне академічне нагромадження відбулося в поєднанні з тим, що називалося третьою хвилею демократизації, яка почалася в середині сімдесятих років, починаючи з півдня Європи, і поширилася протягом десятиліть вісімдесятих та дев"яностих років, увібравши в себе багато країн світу. Демократичний перехід можна визначити як політичний процес встановлення або розширення можливості демократичної участі та лібералізації. Цей процес відображає перерозподіл влади між державою та громадянським суспільством. Він супроводжується появою різних центрів влади та запровадженням політичної дискусії. Стаття зосереджена на механізмах, що призводять до консенсусу між політичними суб"'єктами, які здійснюють цю демократичну трансформацію. Демократичний перехід, таким чином, завжди вимагає механізму переговорів, політичних обговорень, полегшення компромісів між авторитарними політиками та демократичною опозицією та, створення мінімального рівня довіри між цими сторонами. Стратегія політичного компромісу має великий вплив на стабільність суспільства в період демократичного переходу.

У цій статті розглядається концепція демократичного переходу разом із загальними теоріями демократизації та появою досліджень про демократичний перехід. Основна увага приділяється деяким аспектам пояснення теорії демократичного переходу. Автор також досліджує переговори, політичні обговорення та їх вплив на демократичні переходи. У статті визначено шляхи та методи, за допомогою яких відбувається демократичний перехід у цілому світі.

Ключевые слова: демократичні переходи, концепція демократичного переходу, теорії пов "язані з демократичним переходом, хвилі демократизації, арабські країни, механізми демократичного переходу, політичні переговори, політичні актори, політичний компроміс

\section{Problem definition.}

$\mathrm{R}$ ecent legal and political theories often employ the concepts of democratization, democratic transition, and transitional justice that are implemented around the globe, from postapartheid South Africa and post-communist Europe to Latin American, African and lately Arab countries. The concept of "Democratic Transition" or "Democratization" has been a major topic in political science since the second half of the 1970s. Over the past four decades, a large number of books, studies and reports have appeared on this issue at various levels: theoretical and practical, quantitative and qualitative, case studies and comparative studies. The democratic transition literature presented many concepts, theoretical arguments, methodological and analytical approaches to tackle with this phenomenon.

The theoretical studies were also concerned with examining and discussing a wide range of issues and variables related to the transition process, whether in terms of their inputs (causes), their patterns (modes of transmission), or their outputs (the nature of post-transition political regimes). This huge academic accumulation came in conjunction with what was called the 
"third wave of democratization", which started since the mid-seventies of the twentieth century beginning from southern Europe (Portugal, Spain, Greece), and then extending during the decades of the eighties and nineties to include many countries of Latin America, East and Central Europe, Asia and Africa.

The concept of democratization and democratic transition indicates a finalitydriven political process. The final destination of democratic transition is clear from the beginning: a system of democratic government. Despite a number of similarities and overlapping political issues, the process of democratic transition thus clearly needs to be distinguished from postcolonial politics of independence, post conflict peace building, and limited reforms of numerous authoritarian regimes seeking to stabilize power rather than implement full-scale transitions to democracy.

The comparative analysis of the world's democratization tracks contributed to the production of a set of rules, concepts, and assumptions that enabled researchers to describe, analyze, and interpret paths and dynamics that lead to changing political regimes. In this context, a distinct subspecialty emerged in the field of political science that was called "transition science" or democratization studies. The subject of "the science of transition" relates essentially to changing political procedures during the time between the demise of the authoritarian regime and the efforts to establish a democratic system.

Research and publications analysis. Democratic transition was the subject of investigation of many researchers. Democratic transition studies embrace different views of researchers and scientists. They explored the processes that cover the period between the fall of the old regime and the moment when the power is vested in the coming democratic regime entirely. We'll focus on the studies done by some western scientists like A. Przeworski, Ch. Adrian, F. Fukuyama, G. O'Donnell, J. Linz, Ph. Schmitter, S. Huntington, and some
Arab authors, who express different approaches to the concept of democratic transition.

The aim of this article is to shed some light on the theoretical framework that is rooted in the democratic transition process, by exploring the concept, monitoring and analyzing some theories related to democratic transition, the ways and methods through which the transition process is taking place.

The democratic transition is a set of distinct stages that begins with the demise of authoritarian regimes followed by the emergence of modern democracies seeking to consolidate their systems. This process reflects the redistributing of power between the state and the civil society to ensure a balance between the state and the institutions of society. It is accompanied by the appearance of different centers of power and the introduction of the political debate.

Democratic transition thus can be defined as a political process of establishing or enlarging the possibility of democratic participation and liberalization. Liberties and rights to political participation need to be further cemented by constitution making and rule-of-law state building. Despite the variety of democratic regimes, the common understanding of democratic transitions associates these processes with the concept of constitutional and liberal democracy and the political virtues of constitutionalism. Democratization thus involves constitutional transformations and changes commonly described as transitional justice.

Among the approaches to the meaning of democratic transition we'll pay our attention to G. O'Donnell, who considers the democratic transition as a gradual process that crystallizes the context of the state's relationship within society after a protracted political conflict (O’Donnell, Schmitter, \& Whitehead, 1986a).

Another approach to democratic transition belongs to $\mathrm{Ch}$. Adrian. He states that it is the change between systems (Adrian, 1967). By that he means changes in the political system, both deep and shallow, their relations to the 
political dimensions that are represented through the cultural dimensions and everything that democratic transition brings within the combined ideologies and the nature of thinking. They may even affect the basic relationships in societies, customs and traditions of individuals, structural and political transformations, where a political path is followed in a manner different from that of the old path. These changes are caused by the presence of contradictions between the above-mentioned dimensions, which lead to the inability of the existing system to deal with them depending on the old methods. In many cases they generate hybrid systems between what was in the old system and what has been established in the new system.

In F. Fukuyama's book "The End of History" the democratic transitions that occurred in the period between 1980s and 1990s is part of a more general process of global modernization and its respective societal transformation are considered. According to Fukuyama (Fukuyama, 1989), twentieth century was a century of conflict between liberalism and absolutist ideologies such as Fascism and Marxism. The collapse of communism, military regimes, apartheid, and autocracies around the world bears witness to the victory of liberalism and its gathering global force

American scientist S. Huntington introduced a concept of waves of democracy by identifying several historical periods or waves of expansion in democratic politics and decision making that occurred globally. He (Huntington, 1993) described the pattern of global democratization as "a group of transitions from nondemocratic to democratic regimes that occur within a specified period of time" (p. 15). The first wave of modern societies democratization was during the nineteenth century (1828-1926). This period was characterized by S. Huntington as minimal democracy. It was followed by the second wave of democratization that began after the second World War. The third wave of democratization started in southern Europe (Greece, Portugal, Spain) and Latin America (Argentina, Chile) in the period between 1970s-1980s. It spread worldwide and democracy seemed to be like irresistible global tide moving on from one triumph to the next. These waves of transitions were followed by the disintegration of the Soviet bloc countries after the collapse of the Soviet Union in 1991. They were followed by the subsequent dismantlement of autocratic regimes whose existence was based on the Cold War logic, for example, the apartheid system in South Africa (Huntington, 1993, pp. 16-23).

The Middle East and North African countries were not included into democratization waves until Arab Spring revolutions occurred in the end of 2010. Some authors like Eva Bellin, Rafael Bustos and Raymond Hinnebusch argued whether or not the Arab Spring revolutions could be considered as a fourth wave of democratization. In nine years after Arab Spring revolutions, they didn't end up with the establishment of democratic regimes, except for Tunis, which is now still struggling to consolidate its democratic system. Some political and economic reforms with democratic character happened in countries like Morocco, Algeria and Jordan.

The periodization of democratization and democratic transitions into waves assumes that there is a general historical logic and global explanation of these processes. Therefore, the historicizing picture of global democratization is undermined by inconsistencies and comparative flaws in the identification of specific waves. For example, is it possible to consider the democratic transitions in Europe in the 1970s as part of the same process as democratic transitions in Asia in the 1980s and the post-communist countries transitions in the 1990s? Furthermore, the triumphalism of the Western model of liberal democracy and its global primacy have been challenged by the suppression of prodemocracy demonstrations in China in 1989, the establishment of a semi authoritarian regime in Russia, the revival of autocratic populism in Latin America, the return of military rule in Egypt 2013 and other recent forms of nondemocratic politics. 
In his efforts to develop the waves of democratization theory, S. Huntington seeks to explain the democratic transition process in terms of a variety of factors such as economic, cultural, social, and external. His theory draws attention to the importance of international factors and their influence on domestic changes. Regional peculiarities reveal some fundamental differences within the countries that abandoned the authoritarian system and built constitutional democratic statehood. The domestic politics, political traditions, practices, and institutions of such states are mostly affected by the global aspects which play an important role in the process of democratization. Global and local aspects coincide and profoundly affect democratic transitions' chances of success.

There are different subdivisions of theories that explain democratic transition. For example, Pridham and Agh (2001) single out four of them:

"the functionalist, the transnational, the genetic and the interactive. These emphasise or concentrate respectively on socio-economic structural conditions, international influences and trends, political elite strategy and decisions, and lastly the dynamic relationship between the political and socio-economic structural conditions." (p. 6).

Functionalist theories were criticized for focusing on the society and its institutions as a primary unit of analysis and downplaying the role of individual action, also for paying too much attention to material factors. These theories require the existence of the economic development and cultural modernization prerequisites at nation-state level in order for the state to be able to transit to democratic system. Pridham and Agh (2001) study found:

"The combined transformation at both economic and political levels has forced transitologists to take more notes of what D. Rustow called "the deeper layer" of socio-economic conditions and to consider interactions with political democratization... This modification is connected with the view that economic development may not be a necessary prerequisite for democratic transition, but it correlates well with the sustainability of democracy, hence with the consolidation process". (p. 6)

The prevailing tendency for theories before democratic transition theory states that it is necessary to wait for a long time until the social and economic preconditions for the transition to democracy are complete, while democratic transition theory emphasizes the political component by focusing on the behavior of political actors rather than socioeconomic development. Democratic transition theories, therefore, explore the autonomy of politics and consider the processes of decision making and negotiating as the most decisive aspects of political and social democratization.

In 1970, Rustow and Dahl were emphasizing that elite values and beliefs were far more important than mass culture (Diamond, Linz, \& Lipset, 1988). Political elites could bring democracy into being and hold it together as long as they were tolerant, moderate, ready to compromise, peaceful, successful at finding solutions to pressing problems and, above all, convinced that democracy is a better form of government than any other (Lijphart, 1977). This emphasis on elites gathered additional strength during the third wave, and O'Donnell and Schmitter portrayed transitions from authoritarian rule as a complex of voluntarist processes in which elite's strategizing could have a decisive impact.

G. O'Donnell and Ph. Schmitter states that the process of democratic transition begins with the division of the ruling political elites as a result of reforms from above because of economic or social conditions or defeat in a war (O'Donnell, Schmitter, \& Whitehead, 1986a). But this division may open the way to deepening reforms due to popular pressure or alliances between reformist forces in power and the opposition that agree on democratic procedural rules and thereby seek to reduce the uncertainty of a regime transition and its outcome. The nature of the agreement may be decided in a 
formal, explicit pact, whereas in some countries no formal pact is signed. Imposed transitions, in contrast, are designed and implemented unilaterally by ruling autocratic elites with little or no negotiation with opposition elites (Stokke, 2019). The situation varies according to the power of the ruling elite, the economic success of the previous regime, the strength of the opposition, and some other factors. In both cases, however, it requires neutralizing the extremists in the political system and in the opposition. The democratic transition studies focus on the old conflict between the left and the right in southern Europe and South America, and between moderates and extremists, that has become the field of G. O'Donnell and $\mathrm{Ph}$. Schmitter research.

Authors like O'Donnell and Schmitter argue that political elites' attitudes, calculations, and agreements determine if there is a serious possibility of a democratic transition (O’Donnell, Schmitter, \& Whitehead, 1986a). Its main driver is not necessarily economic, the driving motivation of leaders may be completely unexpected from the perspective of those who adopt structural approaches. There are circumstances in which the concern for reputation becomes an example of the importance of satisfying material desires.

In case of Arab countries, before the Arab Spring, there were no serious reforms in Arab political systems. Some of these reforms occurred as a result of external pressure. They were often formal, aimed to silence the opposition and calming the street. After the end of the Cold War, the Western powers, represented by the United States and its allies in Western Europe, no longer needed to support dictatorships to fight communism. They were urging states in Latin America and in other parts of the world to transfer to democratic systems of governing. The Arab region was an exception, where the states have made only cosmetic adjustments in their political systems. Some of the reasons for this exception were rooted in western control over oil resources and providing Israel's security.
A democratically elected government may not allow Western powers to control oil resources, and also such a government may support the desire of the Arab street to announce a political, economic, or military war against Israel, the main US ally. Thus, the US and some western power might lose their influence in the region. Before the Arab Spring, the West dealt with the Arab region with the logic of the Cold War.

The transitions framework builds in several alternative paths. According to Juan Linz, the most important is the urgency of the political opening, which ranges from a speedy extrication to painfully slow transition from above (Linz, 1996). When military wants to extricate itself from responsibility for an economic or military calamity, the transition becomes faster and more certain (Przeworski, 2000). When a military government earns some legitimacy from successful governance, it can dictate the pace and the terms of the transition over a longer period of time, as in case of Egypt in recent days.

Democratic transitions involve a contingent institutional compromise between political elites. As A. Przeworski commented (O’Donnell, Schmitter, \& Whitehead, 1986b):

"If a Peaceful transition to democracy is to be possible, the first problem to be solved is how to institutionalize uncertainty without threatening the interests of those who can still reverse the process." (p. 60)

Since democracy cannot guarantee no one's interests, authoritarian politicians and democratic opposition resort to using the mechanism of negotiations, facilitating compromises, and engendering trust between political elites in order to contain the threat of political violence and avoid chaos and coups against the state.

When Argentina succeeded in the transition to democracy in 1983, there was fear by the military in all of Brazil and Uruguay that the democratic experience will be soon repeated in these countries. Establishing a civil democratic 
system would bring with it the dangers of revanchism, the military would be made responsible for last human rights violations and economic scandals. The new presidents in Brazil Tancredo Neves and Uruguay Julio Sanguinetti had to enter into non-aggression pacts with the army to ensure the army's neutrality in the elections. The pacts provided that in return for the military accepting the result of the elections there would be no investigation or purge of the military following their return to the barracks (Third World Quarterly Journal, 1985).

The positions and tendencies of the political elites in the negotiations determine the future of democracy in the country. Democracy arises as a result of an agreement between the moderates from the regime and the opposition at the outset and the isolation of extremists from both sides (Schienmann, 2005). And they usually agree on the procedural rules but insist on their own principles. This agreement will be the mutual ground between political actors for reestablishing formal institutions that can manage social conflict and the peaceful transition of power.

The strategy of political compromise has a major impact on the stability of society during the democratic transition period. For example, during the Velvet Revolution in Czechoslovakia 1989, the public support for the opposition were being demonstrated in streets and squares, the hardline dominated government was against democratic transition. In these circumstances, however, the political talks are not dominated by the logic of political compromise but by the need to contain the risk of political violence and to facilitate revolutionary change. When representatives of authoritarian regimes are forced by the revolutionary situation to announce the need for political reforms, it is political talks, rather than the legitimately negotiated transitional rules, that guarantee the peaceful nature of a revolution.

The revolutionary situation in case of Tunis in the end of 2010 and popular demonstrations in Algeria in February 2019 didn't lead to political talks between authoritarian regime and the opposition to make political reforms. In fact, it was the army who decided to take a side of the people and remove the president Bin-Ali in Tunis and Bu-Tafliqa in Algeria from presidency and open the road for a democratic transition by allowing the political elections to be held. In this situation, the political talks happened after the removing of the old regime by the army. The political talks started between a new winning party in the new elections and the opposition in spite of the fact that some of the representative of the opposition members belonged to the old authoritarian regime.

To understand the coherence factor of the army in the political system, we should pay attention to the following peculiarity. A democratic transition cannot be successful if its beginning was reformative. The revolutionary events presuppose creating a rift in the authoritarian regime through popular mobilization. There would not be reforms from above. If the army sided with the revolution or was neutral towards the democratization process, then the revolution could succeed in creating a rift in the authoritarian system.

In the case of Egypt 2011, as a result of the demonstrations that lasted 3 weeks, the army pushed President Hosni Mubarak to resign from the presidency and handed over the power to the army. Although the army allowed the establishment of real parliamentary and presidential elections for the first time in modern Egypt's history, it had a special agenda that was later identified after the arrival of the Islamist opposition led by Mohamed Morsi (ruled from 2012, remained in power for a year until the military coup of 2013). The army's pursuit of political power led to the failure of the democratic transition in Egypt before the consolidation process began. What happened in Egypt is similar to what happened in Chile where a democratically elected president ruled for a year and a half before a military coup in 1973 led by Pinochet. After that Pinochet ruled the country for seventeen years. 
In Yemen 2011, the revolution did not reach the overthrow of the regime, but it accomplished a deal to co-govern the country by the authoritarian rule and the opposition. But this partnership failed due to a coup organized by a sectarian political current (The Houthis), which used armed forces to end the process of democratization. There is a large ethnic and sectarian rift in Yemen that had its effect on canceling the democratic transition. Other forces that contributed to this process, were represented by the intervention of countries like Saudi Arabia. This external factor was crucial for the internal affairs in Yemen.

In general, Political talks are considered as the first step towards a competitive multiparty democracy. Furthermore, rules of negotiation and the mutual recognition of opposing parties create conditions that would favor their interests in the newly established political system. When a political compromise is reached between the ruling elite and the opposition forces as a result of a kind of relative balance in the balance of power between the two parties. The ruling elite will be convinced that it is unable to continue with closed policies and repressive practices due to internal and external pressures and that political openness and the transition to some form of a democratic system within an agreement with the opposition that guarantees some of the ruling elite interests.

On the other side, the opposition forces seem unable to overthrow the regime, and therefore find that they have no alternative but to negotiate and bargain with the ruling elite in order to move to democracy. It is noted that negotiations and bargaining between the two sides took place in many cases against the backdrop of popular demonstrations and protests driven by the opposition forces, and repressive practices by the authority. This pattern of transmission has occurred in several countries, including Poland, South Africa, El Salvador, and Nicaragua.

Political talks can represent the absent or weak legitimacy of the authoritarian regime and start the process of democratization by paving the way for a referendum, general democratic elections, and a new constitution. They start as a top-down process of negotiated reforms and systemic changes and open the possibility of political participation and democratic elections or a referendum. The negotiated referenda usually include questions on the form of the state, parliamentary and presidential elections, the formation of a constitutional assembly, etc.

P. Schmitter (1995, pp. 8-12) in his article mentioned twelve lessons he found during his study of the democratic transition processes. We will mention some of them here:

- Democracy is not inevitable and it is revocable. Democracy is not necessary: neither does it fulfill a functional requisite for capitalism, nor does it respond to some ethical imperative of social evolution.

- Transitions from autocratic or authoritarian regimes can lead to diverse outcomes. Four of them seem generically possible, although their probability varies considerably from case to case: (1) regression to autocracy. (2) creation of a hybrid regime. (3) persistence of an unconsolidated democracy or (4) consolidation of a viable democracy.

- Each type of democracy has its own distinctive way of consolidating itself especially its own rhythm and sequence; no single path to consolidation is necessarily a guarantee for the future stability or viability of all types of democracy.

- The eventual outcome of democratization depends in large measure on the sequence with which actors tackle the inevitable multiple transformations that are necessary.

- Transitions to democracy rarely happen in isolation. without the simultaneous presence of other demands and other processes of profound change in socio-economic structures and cultural values.

- The relevance of the international context tends to increase monotonically and to change in intensity with each successive demise of autocracy and attempts to establish democracy. 


\section{Conclusion.}

The theory of democratic transition will remain among the priorities of research agendas in the field of comparative politics in the future because there are new perspectives for research in this field on the one hand. Also, many of the sub-issues associated with it have not yet been resolved, and are still widely debated on the other hand. Common global trends are as important as local, regional, and historical differences, and the general modern drive toward democratization can hardly obscure political contingencies and the reversibility of the whole process. The external factor can play an important role in supporting democratic development in countries that have the capabilities to make them more amenable to democratic transition. Must be one of the lessons that can be learned from different global successful transitions experiences is that the well managed transitional phase for establishing a democratic system on a cleat road map through consensus between the main political actors prevents internal divisions and occurring conflicts thus preserving national unity. This consensus is preceded by many political talks and negotiations to ensure mutual interests of the negotiating parties. The attitudes and tendencies of political elites and the degree of trust to each other to implement the negotiated solution are major factors in determining whether negotiations are successful. The mechanism of negotiation has a major impact on the stability of society during the democratic transition period. The failure of negotiations conducted by the representatives of a political system and the opposition may lead to paralysis of political life and the use of violence to achieve the desired goals by force. Therefore, it is necessary to neutralize the hardliners from the negotiations between the political system and the opposition, and give the way for moderates on both sides to work for a political settlement that will ensure a peaceful transition to democracy. The success of a negotiating process and a political settlement can lead to practices of democracy promotion in terms of producing outcomes that imply a partial and gradual development in line with basic democratic principles.

\section{REFERENCES}

Adrian, Ch. (1967). State and Local Governments. McGraw-Hill, New York. Retrieved from https://www. abebooks.com/9780070004283/State-Local-Governments-charles-adrian-0070004285/plp?cm_sp=plped-_-1-_image.

Diamond, L., Linz, J., \& Lipset, S. (1988). Democracy in Developing Countries. Retrieved from https://www. jstor.org/stable/157032?seq=1.

Fukuyama, F. (1989). The End of History? Center for the National Interest. Retrieved from https://www.embl.de/ aboutus/science_society/discussion/discussion_2006/ref1-22june06.pdf.

Huntington, S. (1993). The Third Wave: Democratization in the Late Twentieth Century. P. 15 (pp. 156-23). The University of Oklahoma, Norman, Publishing Division of the University. Retrieved from https://books.google.com. ua/books?hl=en\&lr=\&id=6REC58gdt2sC\&oi=fnd\&pg=PR11\&dq=Huntington+1993\&ots=S44SJlCDE2\&sig=G4X 7YdlHWn3SRogy1BtWGPnD5YU\&redir_esc=y\#v=onepage\&q=Huntington $\% 201993 \& \mathrm{f}=$ false.

Lijphart, A. (1977). Democracy in Plural Societies: A Comparative Exploration. Yale University Press. Retrieved from https://www.jstor.org/stable/j.ctt1dszvhq.

Linz, J. (1996). Problems of Democratic Transition and Consolidation: Southern Europe, South America, and Post-Communist Europe. The Johns Hopkins University Press. Retrieved from https://books.google.com.ua/books?id $=$ TqRn11AypsgC\&printsec $=$ frontcover\&source $=$ gbs ge summary $r \& c a d=0 \# \mathrm{v}=$ onepage \&q\&f=false.

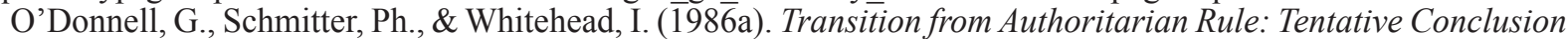
about Uncertain Democracies. The Johns Hopkins University Press. Retrieved from https://books.google.com.ua/ books?hl=en\&lr=\&id=H51Ctdhe $8 \mathrm{scC} \&$ oi $=$ fnd \&pg $=\mathrm{PP} 2 \& \mathrm{dq}=\mathrm{O} \% 27$ Donnell + and + Schmitter + Transitions + from +Authoritarian+Rule:+Comparative+Perspectives\&ots=vbe LqlaxM\&sig=K7rBf5mH57iFQOk1 fxah6GtKu4Q \&redir_esc $=\mathrm{y} \# \mathrm{v}=$ onepage $\& \mathrm{q}=\mathrm{O}^{\prime}$ Donnell $\% 20$ and $\% 20$ Schmitter $\% 20$ Transitions $\% 20$ from $\% 20$ Authoritarian $\% 20$ Rule\%3A\%20Comparative\%20Perspectives\&f=false.

O’Donnell, G., Schmitter, Ph., \& Whitehead, I. (1986b). Transitions from Authoritarian Rule: Comparative Perspectives. (Vol. 3, p. 60). The Johns Hopkins University Press. Retrieved from https://books.google.com.ua/bo oks? id $=5$ HkS5BEBKLsC\&pg $=$ PA60\&lpg $=$ PA60\&dq $=$ the + first + problem + to + be + solved + is + how + to + institutionalize 
+ uncertainty + without + threatening + the + interests + of + those + who + can + still + reverse + the + process $\&$ source $=b 1 \&$ ots $=5$ LeetL8Eu8\&sig=ACfU3U3yeDIVIf-7kH1G93VCzhKqtuHrQw\&hl=en\&sa=X\&ved=2ahUKEwiu562IguzqAhXUw sQBHX1QDdoQ6AEwAHoECDAQAQ\#v=onepage \&q=the $\% 20$ first $\% 20$ problem $\% 20$ to $\% 20$ be $\% 20$ solved $\% 20$ is $\% 20$ how $\% 20$ to $\% 20$ institutionalize $\% 20$ uncertainty $\% 20$ without $\% 20$ threatening $\% 20$ the $\% 20$ interests $\% 20$ of $\% 20$ those $\% 20$ who $\% 20$ can $\% 20$ still $\% 20$ reverse $\% 20$ the $\% 20$ process \&f $=$ false

Pridham, G., \& Agh, A. (2001). Prospects for Democratic Consolidation in East-Central Europe. (p. 6). Manchester University Press. Retrieved from https://books.google.com.ua/books?id=wjtQMZljCHQC\&pg= PA7\&lpg $=$ PA7\& dq $=$ what + is + functionalist + theories + of + democratic + transition $\&$ source $=$ bl\&ots $=$ BbPYUoa g8v\&sig=ACfU3U2j1vQImDh-haxeT4KA BoDPhjomQ\&hl=en\&sa=X\&ved=2ahUKEwiM5airrr3qAhVsioKHW4GCMwQ6AEwAXoECC8QAQ\#v=-onepage\&q=what $\% 20$ is $\% 20$ functionalist $\% 20$ theories $\% 20$ of $\% 20$ democratic $\% 20$ transition $\& \mathrm{f}=$ false

Przeworski, A. (2000). Democracy and Development Political Institutions and Well-Being in the World, 19501990. The Press Syndicate of the University of Cambridge. Retrieved from https://books.google.com.ua/books/about/ Democracy_and_Development.html?id=uiFH5dh12p0C\&redir_esc=y.

Schiemann, J. (2005). The Politics of Pact-Making: Hungary's Negotiated Transition to Democracy in Comparative Perspective. Retrieved from https://books.google.com.ua/books?id=-WLHAAAAQBAJ\&pg=PA27\&lpg=PA27\&dq $=0 \% 27$ donnell + negotiations + between + hardliners + and + softliners\&source $=$ bl\&ots $=$ CSlzRH0vkf\&sig $=$ ACfU3U1e 3 G8u77NtQlkJJbPjF02W9gZGJQ\&hl=en\&sa=X\&ved=2ahUKEwj_6euK2sHqAhXnl4sKHeooCeIQ6AEwAHoECC $0 Q A Q \# \mathrm{v}=$ onepage $\& \mathrm{q}=\mathrm{O}^{\prime}$ donnell $\% 20$ negotiations $\% 20$ between $\% 20$ hardliners $\% 20$ and $\% 20$ softliners $\& \mathrm{f}=$ false.

Schmitter, Ph. (1995). Is It Safe for Transsitologists \& Consolidiologits to travel to the Middle East and North Africa? (pp. 8-12). Standford University. Retrieved from https://fsi-live.s3.us-west-1.amazonaws.com/s3fs-public/ evnts/media/Article - M-EAST3.pdf.

Stokke, K., \& Aüng, S. (October 2019). Transition to Democracy or Hybrid Regime? The Dynamics and Outcomes of Democratization in Myanmar. Eur J Dev Res, 32, 274-293. Retrieved from https://link.springer.com/ article/10.1057/s41287-019-00247-x.

Third World Quarterly. (1985). Editorial: On Negotiating Democratic Transition. Taylor \& Francis, Ltd. Retrieved from https://www.jstor.org/stable/3991598?seq=1.

\section{Харб Мустафа}

Аспірант

Харківський національний університет

ім. В. Н. Каразіна

Email: mustafa.harb07@gmail.com

Цитування: Харб, М. (2020) Теоретичні основи демократичного переходу: механізми демократизації. Науково-теоретичний альманах «Грані», 23 (6-7), 55-64. doi: 10.15421/172065

Citation: Harb, M. (2020). Theoretical Framework of Democratic Transition: Mechanisms of

Democratization. Scientific and theoretical almanac «Grani», 23 (6-7), 55-64. doi: 10.15421/172065

Стаття надійшла / Article arrived: 12.08.2020

\author{
Harb Mustafa \\ Ph.D. Student \\ V. N. Karazin Kharkiv National University
}

